Tropical Journal of Pharmaceutical Research April 2018; 17 (4): 661-668

ISSN: $1596-5996$ (print); 1596-9827 (electronic)

(C) Pharmacotherapy Group, Faculty of Pharmacy, University of Benin, Benin City, 300001 Nigeria.

\title{
Identification of novel anticancer terpenoids from Prosopis juliflora (Sw) DC (Leguminosae) pods
}

\author{
Shazia Kanwal Malik ${ }^{1}$, Maqsood Ahmed ${ }^{2}$, Farah Khan ${ }^{1 \star}$ \\ ${ }^{1}$ Molecular Genetics \& Biotechnology Laboratory, Botany Department, ${ }^{2}$ Riphah Institute of Pharmaceutical Sciences, Riphah \\ International University, Lahore, Pakistan
}

*For correspondence: Email: drfarah_khann@yahoo.com; Tel: +92-3334743668

Sent for review: 2 December 2017

Revised accepted: 23 March 2018

\begin{abstract}
Purpose: To identify a novel source of terpenoid anticancer compounds from P. juliflora (Sw.) DC. (Leguminosae) pods as a medicinal substitute for cancer medicines.

Methods: The pods were collected, dried and pulverized. The ethanol extract was prepared by maceration. Various phyto-constituents were detected in the extract by UV-VIS spectroscopy at a wavelength ranging from $200-800 \mathrm{~nm}$. The molecular formula, chemical structure, and percent peak area of these phyto-constituents were determined by gas chromatography-mass spectrometry (GC-MS). attenuated total reflectance Fourier transform infrared spectroscopy (ATR-FTIR) was used for functional group determination of bioactive compounds.

Results: P. juliflora pods were rich in tannins, carotenoid and terpenoids. Nineteen bioactive compounds were detected. Out of these, thirteen are here reported for the first time with four of them exhibiting anticancer activities, while two belong chemically to terpenoids. Furthermore, FTIR established characteristic peaks for the various biologically-active functional groups.

Conclusion: The results show that $P$. juliflora pods is a valuable source of anticancer, antitumor and chemoprotective compounds, especially terpenoids, that can potentially be developed as alternatives to current painful and costly cancer therapies.
\end{abstract}

Keywords: Prosopis juliflora (Sw.) DC., Anticancer terpenoids, Attenuated total reflectance-FTIR, Herbal medicine

This is an Open Access article that uses a funding model which does not charge readers or their institutions for access and distributed under the terms of the Creative Commons Attribution License (http://creativecommons.org/licenses/by/4.0) and the Budapest Open Access Initiative (http://www.budapestopenaccessinitiative.org/read), which permit unrestricted use, distribution, and reproduction in any medium, provided the original work is properly credited.

Tropical Journal of Pharmaceutical Research is indexed by Science Citation Index (SciSearch), Scopus, International Pharmaceutical Abstract, Chemical Abstracts, Embase, Index Copernicus, EBSCO, African Index Medicus, JournalSeek, Journal Citation Reports/Science Edition, Directory of Open Access Journals (DOAJ), African Journal Online, Bioline International, Open-J-Gate and Pharmacy Abstracts

\section{INTRODUCTION}

Cancer (tumor or neoplasm) is a broad word used for a large group of diseases that can affect any part of the human body. Unfortunately, in low- and middle-income countries especially Pakistan and India, $70 \%$ of deaths occur from cancer [1]. In 2012, breast, lip, oral cavity, lung and liver cancers were increased including
Hepatitis and Human Papilloma Virus (HPV) resulting into $25 \%$ of cancer cases in Pakistan [2]. According to WHO, the overall economic impact of cancer on low income countries is increasing. The total annual economic cost of cancer in 2010 was estimated at approximately US\$ 1.16 trillion [3,4].

Medicinal plants have been used orally and as 
herbal infusions to treat various ailments and serious diseases [5]. P. juliflora is an ornamental traditional medicinal tree. It grows in arid and semi-arid regions of Indo-Pak region and has been used as a folk remedy for catarrh, cold, diarrhea, dysentery and excrescences [6]. In different studies it has been revealed that its fruits contain terpenoids, phenol, saponin and tannins with proven pharmacological activities $[7,9]$.

Plant terpenoids are extensively used for their aromatic qualities and have played a role in traditional herbal remedies in India and China $[10,11]$.

Since the discovery of terpenes, more than 150 years ago, scientists have identified and isolated more than 50,000 terpenoids. But the source of medicinal terpenoids, was mainly fungi. In the current study, a plant source was used for the first time, to identify anticancer terpenoids. Identification and confirmation of natural compounds is a crucial and vital step for anticancer drug discovery. GC-MS is a very powerful technique towards the specific detection and potential identification of compounds. For detailed screening of terpenoids, ultravioletvisible spectroscopy [12], attenuated total internal Reflectance-Fourier transform infrared spectroscopy for functional group detection and GC-MS were used [13].

\section{EXPERIMENTAL}

\section{Plant material}

The pods of $P$. juliflora were picked from Jinnah Garden, Lahore, Pakistan during summer season, 2017 and identified by a taxonomist, Dr Zubaida Yousaf (Department of Botany, Lahore College for Women University). A voucher specimen (no. LCWU-15-128) was deposited in Prem Madam Herbarium, Department of Botany, Lahore College for Women University, Lahore, Pakistan.

\section{P. juliflora pods extraction}

$P$. juliflora pods were cut, shade dried, and powdered for further use. Two grams of powdered pods were extracted with $50 \mathrm{~mL}$ of ethanol with gentle stirring for $72 \mathrm{~h}$, filtered and crude extract was collected.

\section{$P$. juliflora extract analysis}

Freshly prepared extract was exposed to standard methods of phytochemical analysis to detect the constituents, viz. terpenoids, flavonoids, alkaloids, phenolics and glycosides [14]. In our previous experiment, we have also investigated the qualitative and quantitative terpenoid contents with high anti-oxidative potential $[9,15]$.

For UV-VIS analysis, the extract was centrifuged at $2000 \mathrm{rpm}(15 \mathrm{~min})$ and processed through micro filters. The sample was diluted to $1: 4$ with ethanol. The extract was scanned using wavelength ranging from $200-900 \mathrm{~nm}$ through Perkin Elmer Spectrophotometer and the characteristic peaks were noticed.

ATR- FTIR analyzed the phyto-constituent in extract. Infrared spectra were obtained with a Harrick Split-pea ATR microscope interfaced to a Perkin Elmer 2000 Fourier transform infrared spectrometer with a single bounce diamond ATR cell. Spectra over the $4000-1000 \mathrm{~cm}^{-1}$ range were recorded in \% transmittance mode to fetch the characteristic peaks of the functional groups. The collected data are processed by optical user software.

The phytochemical constituents were determined by GC-MS analysis system (Clarus 500 , Perkin Elmer, CT, USA) containing Agilent DB-5 (Thomas no. 2713R99) with specification (5\% diphenyl dimethyl polysiloxane, $30 \mathrm{~m} \times 0.25 \mathrm{~mm}$ $\times 0.25 \mu \mathrm{m}, 5$ cage). Constant flow of Helium gas was maintained at $1 \mathrm{~mL} / \mathrm{min}$. The oven temperature was maintained at $110^{\circ} \mathrm{C}$ for 2 min and then increased to $280^{\circ} \mathrm{C}$ in $9 \mathrm{~min}$. Aliquots $(2 \mu \mathrm{L})$ of ethanol extract were injected into the instrument, injector temperature was $250^{\circ} \mathrm{C}$. The MS detection took $36 \mathrm{~min}$ to screen the predominant constituents with computer-driven algorithm and using mass spectrum library (NIST version 2.0, 2005) [17]. Turbomass 5.2 software program was used in the analyzer.

\section{RESULTS}

\section{Phytochemical profile}

Qualitative phytochemical analysis of pods extract indicated the presence of terpenoids, falvonoids, phenols, quinine, saponins, glycosides and alkaloids.

\section{UV-Vis spectra}

The spectrum showed the peaks at 248.0,306.0, $372.0,452.0,532.0,658.0 \mathrm{~nm}$ with the absorption of $0.921,0.912,0.764,1.030,0.587$ and 0.321 respectively. The results are presented in Figure 1 and Table 1. 


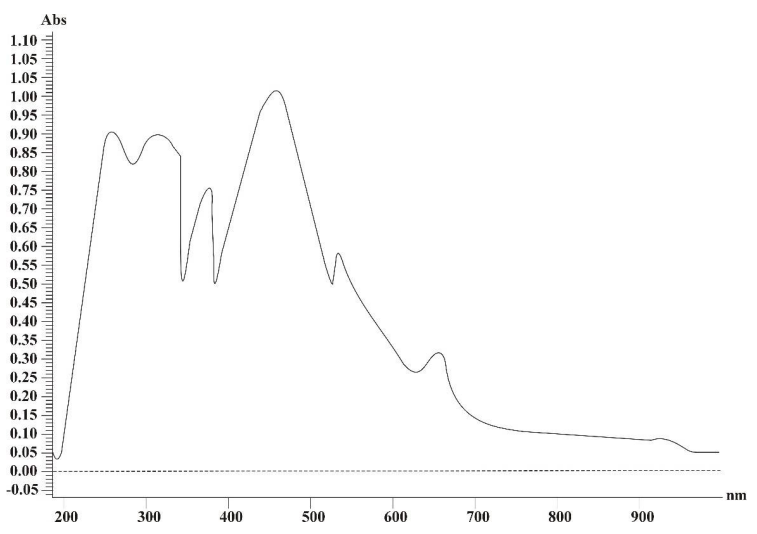

Figure 1: UV-VIS absorption spectra of ethanolic extract of $P$. juliflora pods

Table 1: UV-VIS peak values of ethanol extract of $P$. juliflora pods

\begin{tabular}{lcl}
\hline $\begin{array}{l}\text { Wavelength } \\
\text { (nm) }\end{array}$ & Absorption & Compound \\
\hline 658.0 & 0.321 & Nf \\
532.0 & 0.587 & Tannins \\
452.0 & 1.030 & Carotenoid \\
372.0 & 0.764 & Terpenoid \\
306.0 & 0.912 & Terpenoid \\
248.0 & 0.921 & Terpenoid \\
\hline
\end{tabular}

\section{ATR-FTIR spectra}

ATR-FTIR spectrum of $P$. juliflora pods extract was determined. The data interpreted from the infrared spectral pattern were given and detected as 8 peaks in Table 2. FTIR spectrum was used to identify functional group of active components present in extract [16]. ATR-FTIR spectrum analysis showed the presence of alkane $(\mathrm{C}-\mathrm{H})$, aldehyde $(\mathrm{C}-\mathrm{H})$, aromatic $(\mathrm{C}=\mathrm{C})$, secondary alcohol $(\mathrm{C}-\mathrm{O})$, amine $(\mathrm{C}-\mathrm{N})$, aromatic $(\mathrm{C}-\mathrm{H})$ with bands assignment located at 2975.29, 2943.42, 2832.51, 2349.34, 1449.57, 1087.87, $1024.22,880.52 \mathrm{~cm}^{-1}$, respectively (Figure 2).

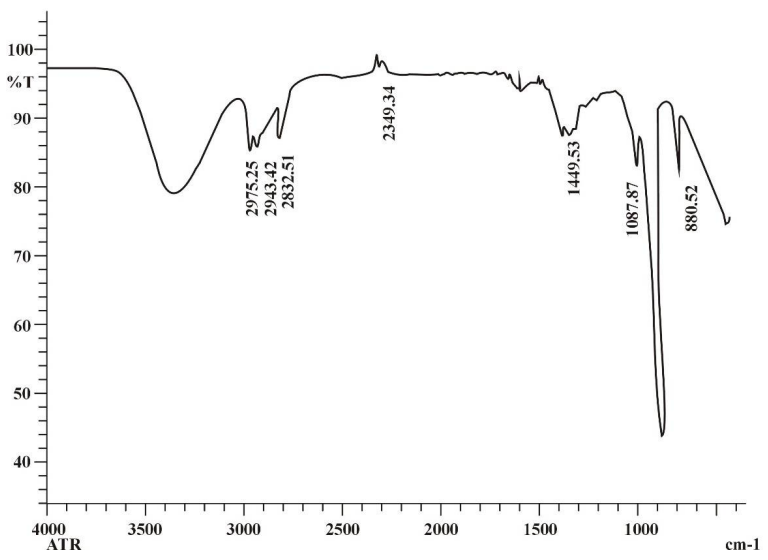

Figure 2: FTIR spectra of ethanol extract of $P$. juliflora pods with peak values and functional groups
Table 2: FTIR spectral peak values and functional groups obtained from ethanol extract of $P$. juliflora pods

\begin{tabular}{lll}
\hline $\begin{array}{l}\text { Peak } \\
\text { value }\end{array}$ & $\begin{array}{l}\text { Type of } \\
\text { vibration }\end{array}$ & $\begin{array}{l}\text { Bond/functional } \\
\text { group }\end{array}$ \\
\hline 880.52 & bending & $\mathrm{C}-\mathrm{H} /$ Aromatic \\
1024.22 & stretching & $\mathrm{C}-\mathrm{N} /$ Amine \\
1087.87 & stretching & $\mathrm{C}-\mathrm{O} /$ Secondary \\
& & alcohol \\
1449.57 & bending & $\mathrm{C}=\mathrm{C} /$ Aromatic \\
2349.34 & stretching & $\mathrm{O}=\mathrm{C}=\mathrm{O}$ \\
2832.51 & stretching & $\mathrm{C}-\mathrm{H} /$ Aldehyde \\
2943.42 & stretching & $\mathrm{C}-\mathrm{H} /$ Alkane \\
2975.29 & stretching & $\mathrm{C}-\mathrm{H} /$ Alkane \\
\hline
\end{tabular}

\section{GC-MS data}

Interpretation of GC-MS was conducted by comparing spectrum, SI (similarity index), RT (retention time) and $\mathrm{RI}$ (retention indices) of the unknown component with database of NIST with 62,000 patterns and Scifinder having more than 250,000 patterns of compounds. The percentage relative amounts of all components were calculated by comparing it average peak areas to the total areas. The biological activity of the compound was based on Duke's Phytochemical and ethnobotanical Databases by Jim Duke (Agricultural Research Service/USDA) [17]. The name, molecular weight and structure of chemical motifs of the test materials were presented in Tables $(3,4,5)$ and Figure 3.

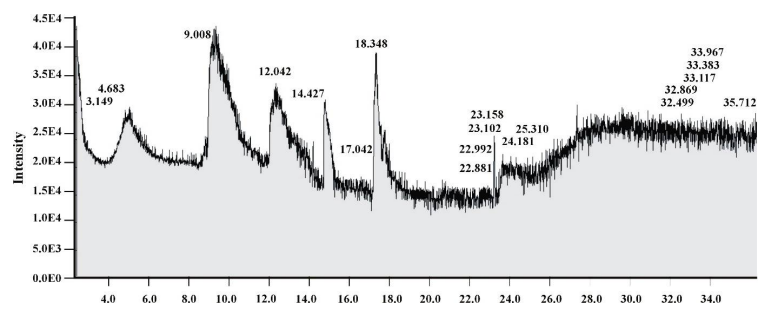

Figure 3: Chromatogram of ethanol extract of $P$. juliflora pods

\section{DISCUSSION}

Pakistan being an agricultural land is a precious source of medicinal as well as ornamental plants. A huge population of Pakistan cannot afford costly imported anticancer synthetic medicines. Terpenoids will not only reduce economic burden but also provide local medication with low side effects.

Spectroscopic methods are becoming a powerful analytical tool for secondary metabolite profiling as well as the qualitative and quantitative fingerprinting of bioactive compounds. 
Table 3: Identified bioactive compounds of ethanol extract of $P$. juliflora by GC-MS (contd)

\begin{tabular}{|c|c|c|c|c|c|c|c|}
\hline Compound name & $\begin{array}{l}\text { Molecular } \\
\text { formula }\end{array}$ & Chemical structure & $\begin{array}{l}\text { Molecular } \\
\text { weight }\end{array}$ & $\begin{array}{l}\text { Peak area } \\
(\%)\end{array}$ & $\begin{array}{l}\text { Retention } \\
\text { Time }\end{array}$ & $\begin{array}{l}\text { Terpeniod } \\
\text { Y/N }\end{array}$ & Therapeutic activity \\
\hline $\begin{array}{l}-1 \text {-methoxy-2-propyl } \\
\text { acetate }\end{array}$ & $\mathrm{C}_{6} \mathrm{H}_{12} \mathrm{O}_{3}$ & & 132.157 & 0.23 & 3.149 & 口Y & $\mathrm{Nf}$ \\
\hline -Ethyne, fluoro- & $\mathrm{C}_{2} \mathrm{HF}$ & $=$ & 44.027 & 0.57 & 4.683 & $\mathrm{~N}$ & $\mathrm{Nf}$ \\
\hline $\begin{array}{l}\text { Pentanal } \\
\text { ( n-Pentanal) }\end{array}$ & $\mathrm{C}_{5} \mathrm{H}_{10} \mathrm{O}$ & & 86.132 & 5.41 & 9.008 & $\mathrm{~N}$ & $\begin{array}{l}{ }^{*} \text { Antitumor (Nasopharynx), Neurogenic, Increase natural killer } \\
\text { cell activity, Nephroprotective, Neuroprotective, GABA-nergic }\end{array}$ \\
\hline $\begin{array}{l}\text { Butyramide } \\
\text { (n-Butylamide) }\end{array}$ & $\mathrm{C}_{4} \mathrm{H}_{9} \mathrm{NO}$ & & 87.120 & 0.39 & 12.042 & $\mathrm{~N}$ & $\begin{array}{l}{ }^{*} \text { Antitumor (Nasopharynx), Neurogenic, Increase natural killer } \\
\text { cell activity, Nephroprotective, Neuroprotective, GABA-nergic }\end{array}$ \\
\hline -Cyclobutanol & $\mathrm{C}_{4} \mathrm{H}_{8} \mathrm{O}$ & & 72.105 & 1.61 & 14.427 & $\mathrm{~N}$ & $\mathrm{Nf}$ \\
\hline -1-Methyldecylamine & $\mathrm{C}_{11} \mathrm{H}_{25} \mathrm{~N}$ & & 171.322 & 1.02 & 17.042 & $\mathrm{~N}$ & $\mathrm{Nf}$ \\
\hline $\begin{array}{l}\text { n-Hexadecanoic acid } \\
\text { (Glycon P-45) }\end{array}$ & $\mathrm{C}_{16} \mathrm{H}_{32} \mathrm{O}_{2}$ & In & 256.424 & 5.20 & 18.348 & $\mathrm{aY}$ & $\begin{array}{c}\text { * Anticancer (Pancreas, Pharynx, Prostate), Anticarcinomic } \\
\text { (Pancreas, Prostate), Antitumor (Breast, Lung, Prostate, } \\
\text { Pancreas), Antidote Poison Gas, DNA-Protective, P21-Inducer, } \\
\text { P450-1A-Inducer, P450-2B-Inducer, Antitumor-Promoter, } \\
\text { Cancer-Preventive (Esophagus), Provide Silicon, Provide Vit D, } \\
\text { K and Zinc, Ulcer Protective }\end{array}$ \\
\hline
\end{tabular}


Table 4: Identified bioactive compounds of ethanol extract of $P$. juliflora by GC-MS (contd)

\begin{tabular}{|c|c|c|c|c|c|c|c|}
\hline Compound name & $\begin{array}{l}\text { Molecular } \\
\text { formula }\end{array}$ & Chemical structure & $\begin{array}{l}\text { Molecular } \\
\text { weight }\end{array}$ & $\begin{array}{l}\text { Peak area } \\
(\%)\end{array}$ & $\begin{array}{l}\text { Retention } \\
\text { Time }\end{array}$ & $\begin{array}{l}\text { Terpeniod } \\
\mathrm{Y} / \mathrm{N}\end{array}$ & Therapeutic activity \\
\hline $\begin{array}{l}\text {-Dibutyl phthalate } \\
\text { (Genoplast B) }\end{array}$ & $\mathrm{C}_{16} \mathrm{H}_{22} \mathrm{O}_{4}$ & & 278.343 & 0.65 & 22.881 & वY & $\begin{array}{c}\text { *Anticancer (Breast, Bladder), Antitumor (Brain, Breast, } \\
\text { Lung, Prostate, Bladder), Anticarcinomic (Breast), Fat } \\
\text { Burning, Hormone Balancing, Increase Vit K, D, Zinc and } \\
\text { calcium Bioavailability }\end{array}$ \\
\hline Hydroxyurea & $\mathrm{CH}_{4} \mathrm{~N}_{2} \mathrm{O}_{2}$ & & 76.055 & 0.15 & 22.992 & $\mathrm{~N}$ & $\begin{array}{l}{ }^{* *} \text { In Vivo Anticancer Drug Screen, Anti-proliferative } \\
\text { against P388 leukemic cell, Inhibition of human CA9 }\end{array}$ \\
\hline -3-Hydroxybutanal & $\mathrm{C}_{4} \mathrm{H}_{8} \mathrm{O}_{2}$ & & 88.105 & 0.12 & 23.102 & $\mathrm{~N}$ & $\mathrm{Nf}$ \\
\hline $\begin{array}{l}\text {-Cyclopropaneoctano } \\
\text { ic acid, } \\
2-[[2-[(2- \\
\text { ethylcyclopropyl) } \\
\text { methyl]cyclopropyl]m } \\
\text { ethyl]-, methyl ester }\end{array}$ & $\mathrm{C}_{22} \mathrm{H}_{38} \mathrm{O}_{2}$ & & 334.535 & 0.16 & 23.158 & $\mathrm{~N}$ & ( \\
\hline $\begin{array}{l}\text { 2,4-Dihydroxy-2,5- } \\
\text { dimethyl-3(2H)-furan- } \\
\text { 3-one }\end{array}$ & $\mathrm{C}_{6} \mathrm{H}_{8} \mathrm{O}_{4}$ & & 144.125 & 0.06 & 24.181 & $\mathrm{~N}$ & $\begin{array}{c}\text { *Anti-HIV-Integrase, Antidote (Heavy Metals, Hydrazine, } \\
\text { Hypoglycin-A), Hepatoprotective, Hormone Balancing, } \\
\text { Improve Cerebral Hypoxia }\end{array}$ \\
\hline
\end{tabular}


Table 5: Identified bioactive compounds of ethanol extract of $P$. juliflora by GC-MS (contd)

\begin{tabular}{|c|c|c|c|c|c|c|c|}
\hline Compound name & Molecular formula & Chemical structure & $\begin{array}{c}\text { Molecular } \\
\text { weight }\end{array}$ & Peak area (\%) & $\begin{array}{l}\text { Retention } \\
\text { Time }\end{array}$ & $\begin{array}{c}\text { Terpeniod } \\
\mathrm{Y} / \mathrm{N}\end{array}$ & $\begin{array}{c}\text { Therapeutic } \\
\text { activity }\end{array}$ \\
\hline $\begin{array}{l}\text {-Methyl 5-(2-undecylcyclopropyl) } \\
\text { Pentanoate }\end{array}$ & $\mathrm{C}_{20} \mathrm{H}_{38} \mathrm{O}_{2}$ & & 310.514 & 0.07 & 25.310 & $\mathrm{~N}$ & ${ }^{*}$ Methyl-Donor \\
\hline -Ergosterol, acetate & $\mathrm{C}_{30} \mathrm{H}_{46} \mathrm{O}_{2}$ & & 438.685 & 0.06 & 32.499 & $\mathrm{~N}$ & $\mathrm{Nf}$ \\
\hline -Maymyrsine & $\underline{\mathrm{C}}_{32} \underline{\mathrm{H}}_{37} \underline{\mathrm{NO}}_{10}$ & & 595.645 & 0.03 & 32.869 & $\mathrm{~N}$ & $\mathrm{Nf}$ \\
\hline -"Cycloartanol & $\underline{\mathrm{C}}_{30} \underline{\mathrm{H}}_{52} \underline{\mathrm{O}}$ & & 428.745 & 0.04 & 33.117 & $\mathrm{~N}$ & ${ }^{* *}$ Antiviral \\
\hline -Carpesterol Benzoate & $\underline{\mathrm{C}}_{44} \underline{\mathrm{H}}_{58} \underline{\mathrm{O}}_{5}$ & & 666.943 & 0.05 & 33.383 & $\mathrm{~N}$ & $\mathrm{Nf}$ \\
\hline Carpesterol Dehydrate & $\underline{\mathrm{C}}_{37} \underline{\mathrm{H}}_{52} \underline{\mathrm{O}}_{3}$ & & 544.821 & 0.02 & 33.967 & $\mathrm{~N}$ & $\mathrm{Nf}$ \\
\hline -.9-(2-oxiranyl)-1-nonanol & $\underline{\mathrm{C}}_{11} \underline{\mathrm{H}}_{22} \underline{\mathrm{O}}_{2}$ & . & 186.295 & 0.04 & 35.712 & $\overline{\square Y}$ & $\mathrm{Nf}$ \\
\hline
\end{tabular}


The qualitative UV-Vis spectroscopy of ethanol extract of $P$. juliflora displayed characteristic peaks of major bioactive compounds like terpenoid, carotenoids and tannins. The results obtained were confirmed by comparing the absorption values and wavelength with already published research data [18]. These results showed that the pods are rich source of terpenoids [15]. Previously, (-) mesquitol was isolated from $P$. juliflora, heartwood [19]. The antibacterial properties of alkaloid from $P$. juliflora were also determined [6]. There seems a connection between terpenoids and antimicrobial activity, hence, we used pods for the first time to identify anticancer terpenoids and fortunately, we are successful. It will bring a revolution in cancer treatment with less side effects and low cost. Many scientists proposed that terpenoids are natural products for cancer therapy [20].

Previously, we revealed that $P$. juliflora pods had $25 \%$ of total terpenoid contents [15], and these may be major contributing factors for the highest antioxidant potential of pods by DPPH free radical scavenging activity (92\%) with $\mathrm{IC}_{50}$ $(0.045 \pm 0.005)$ [9].

For further confirmation of bioactive compounds, these findings must be supplemented with other analytical techniques like FTIR and GC-MS, for proper extract characterization and finger-printing of metabolites. The FTIR spectrum identifies the functional group of the active components on the basis of peak value in infrared radiation region. The functional groups were identified by comparing the wavelength of the phytochemicals with infrared spectroscopy absorption Table published online by UC Davis ChemWiki and OChemonline. The results confirmed the presence of phenol, cyclohexane, alkene and aromatic compounds [18].

Functional groups play in the activity of secondary metabolites, their kinetics, and overall role in chemical activity and therapeutic functioning of compounds [21].

GC-MS analysis identified 19 bioactive compounds comprising 5 anticancer compounds with 2 novel anticancer compounds and 2 anticancer terpenoids from the ethanol extract of pods of $P$. juliflora (Figure, 3). Furthermore, for the first time, in the pods a total of 13 novel compounds, 2 anticancer compounds have been identified i.e. dibutyl phthalate and hydroxyurea. Dibutyl phthalate (Genoplast B), magnificent potential compound against breast and bladder cancer. Similarly, hydroxyurea $(0.15 \%)$ has been used in in vitro anticancer drug screening. Although alkaloids were identified from $P$. juliflora, but they are used under different sources like heartwood and leaves $[6,19]$.

Previously, these terpenoids have been synthetically produced or obtained from microbes like fungi, bacteria and marine organisms [22].

\section{CONCLUSION}

The findings of this study indicate that $P$. juliflora pods are a novel source of anticancer, chemopreventive and medicinally important bioactive compounds, especially terpenoid. Thus, further investigations, including preclinical studies are recommended on cancer animal model.

\section{DECLARATIONS}

\section{Acknowledgement}

We are greatly obliged to the Molecular genetics and Biotechnology Lab, Department of Botany, Central Lab, Lahore College for Women University, Riphah Institute of Pharmaceutical Sciences, Riphah International University, Lahore, Pakistan and spiritual scientist Mr. Khawajja Shamsuddin Azeemi and Mr. Junaid Raja Azeemi for the successful completion of this research work.

\section{Conflict of interest}

No conflict of interest is associated with this work.

\section{Contribution of authors}

We declare that this work was done by the authors named in this article and all liabilities pertaining to claims relating to the content of this article will be borne by the authors. Shazia Kanwal Malik conceived and designed the study. Shazia Kanwal Malik, Masood Ahmad, Farah Khan collected and analyzed the data. Shazia Kanwal Malik, Masood Ahmad, Farah Khan wrote the manuscript.

\section{REFERENCES}

1. Ferlay J, Soerjomataram I, Ervik M, Dikshit R, Eser $S$ and Mathers C. GLOBOCAN 2012 v1.0, Cancer Incidence and Mortality Worldwide: IARC Cancer Base No. 11 Lyon, France: International Agency for Research on Cancer 2013.

2. Sarwar MR, Saqib A. (2017). Cancer prevalence, incidence and mortality rates in Pakistan. Cognet Medicine 2012; 4: 1-13. 
3. Olsen AH, Njor SH, Vejborg I, Schwartz W, Dalgaard P, Jensen MB, Tange UB, Blichert-Toft $M$, Rank $F$, Mouridsen $H$, et al. Breast cancer mortality in Copenhagen after introduction of mammography screening: cohort study. BMJ 2005; 330-220.

4. Global Burdon of Diseases 2015 Risk Factors Collaborators. Global, regional, and national comparative risk assessment of 79 behavioral, environmental and occupational, and metabolic risks or clusters of risks, 1990-2015: a systematic analysis for the Global Burden of Disease Study 2015. Lancet 2016; 388 (10053): 1659-1724.

5. Pico $Y$ and Kozmutza $C$. Evaluation of pesticide residue in grape juices and the effect of natural antioxidants on their degradation rate. Anal. Bioanal. Chem 2007; 389: 1805-1814.

6. Singh $S$ and Swapnil VS. Antibacterial properties of alkaloid rich fractions obtained from various parts of Prosopis juliflora. Int J Pharma Sci Res 2011; 2: 114-20.

7. Kumudhavalli MV, Mohit V, Jayakar B. Phytochemical and pharmacological evaluation of the plant fruit of Terminalia belerica Roxb. IJPLS 2010; 1: 1-11.

8. Vedak S, Raut SV. Study on antibacterial compounds from methanolic extract of bark of Prosopis juliflora (Vilayati babhul). Int J Pharmaceu Sci Bus Manag 2014; 2: 1-14.

9. Malik SK, Ahmad M. and, Khan F. Estimation of radical scavenging potential of selected medicinal plants of Lahore, Pakistan. PJS 2017; 69: 246-250.

10. Burgess $C$, Cornelius V, Love S, Graham J, Richards $M$ and, Ramirez A. Depression and anxiety in women with early breast cancer: five-year observational cohort study. BMJ 2005; 330-702.

11. Plummer M, de Martel C, Vignat J, Ferlay J, Bray $F$ and, Franceschi S. Global burden of cancers attributable to infections in 2012: a synthetic analysis. Lancet Glob
Health 2016; 4: 9 doi: 10.1016/S2214-109X (16)301437.

12. Antony TS, Peter MJ and, Raj, JY. Phytochemical Analysis of Stylosanthes fruticosa using UV-VIS, FTIR and GCMS. RJCS 2013; 3: 14-23.

13. Baseri MK and, Baker S. Identification of Cellular Components of Medicinal plants using FTIR. Romanian J. Biophys 2011; 21: 277-284.

14. Harborne AJ. Phytochemical methods a guide to modern techniques of plant analysis. Springer science \& business media 1998; 4-84.

15. Malik SK, Ahmad M, Khan F. Qualitative and quantitative estimation of terpenoid contents in some important plants of Punjab, Pakistan, PJS 2017; 69: 151-154.

16. Anjali PK, Jain SP and, Bhawsar J. Phytochemical analysis of Mentha spicata plant extract using UV-VIS, FTIR and GC/MS technique. J. CHEM 2016; 8: 1-6.

17. Duke JA, Beckstrom-Sternberg SM. Dr. Duke's phytochemical and ethnobotanical databases 1994.

18. Jain D, Daima HK, Kachhwaha S, Kothari SL. Synthesis of plant-mediated silver nanoparticles using papaya fruit extract and evaluation of their anti-microbial activities. Dig J Nanomater Biostruct 2009; 4(3): 557-563.

19. Sirmah P, Dumarcay S, Masson E, Gerardin P. Unusual amount of (-)-mesquitol from the heartwood of Prosopis juliflora. Nat. Prod. Res 2009; 23: 183-189.

20. Huang M, Lu J J, Huang MQ, Bao JL, Chen XP and, Wang YT. Terpenoids: natural products for cancer therapy. Expert Opin Investig Drugs 2011; 21: 18011818.

21. Berdy J. Bioactive microbial metabolites. A personal view. J. Antibiot 2005; 45: 581-26 and 43: 57-90.

22. Joint I, Mühling M and Querellou JJ. Culturing marine bacteria: an essential prerequisite for biodiscovery. Microb Biotechnol 2010; 3: 564-575. 